\title{
EXTENDING THE SIZE LIMITS OF CAST/WROUGHT SUPERALLOY INGOTS
}

\author{
Ann D. Helms, Charles B. Adasczik, and Laurence A. Jackman \\ Teledyne Allvac \\ 2020 Ashcraft Avenue \\ Monroe, North Carolina 28110
}

\begin{abstract}
Larger, more aggressive jet engine and industrial gas turbine designs have increased the demand for large diameter premium superalloy billets for rotating component applications. Forging suppliers are requesting larger diameter billet with structures and properties equivalent to smaller diameter billet. This requires larger diameter ingots since grain size in forging billet is strongly dependent on the amount of work imposed to the starting ingot structure. However, ingot diameter has been limited by segregation tendencies. This paper summarizes the development of larger diameter superalloy ingots for these applications. Much of the work focuses on alloy 718 , but advances gained in this alloy system have been applied to alloys 706, 720, and Waspaloy. Extensive process development has been necessary to establish robust practices with defined process windows for each alloy. All steps of the total melt process must be evaluated but special emphasis has been placed on the final melt process where several melt parameters need to be evaluated. Sometimes thermal treatments of electrodes are necessary to prevent melt rate cycles during remelting. Development programs now underway are also presented.
\end{abstract}

\section{Introduction}

Large diameter solid solutioned strengthened and low hardener superalloy ingots have been routinely melted for many years. However, meeting the demands of jet engine and land based turbine industries for large diameter ingots of high hardener superalloy systems is challenging because of the strong tendency these alloys have towards macrosegregation and microsegregation. Also, their lower ductility can lead to internal cracks from thermal gradients created during heating and cooling operations. Development programs to meet this challenge must take advantage of all available technology. This presentation reviews recent programs to develop larger diameter ingots in gamma prime and in gamma double prime nickel-base superalloy systems. For each alloy system, two alloys that cover a wide range of hardener levels are discussed. The four alloys and their chemical compositions are given in Table $\mathrm{I}$.

Superalloys 1996

Edited by R. D. Kissinger, D. J. Deye, D. L. Anton,

A. D. Cetel, M. V. Nathal, T. M. Pollock, and D. A. Woodford

The Minerals, Metals \& Materials Society, 1996
Table I. Nominal Alloy Compositions in Weight Percent

\begin{tabular}{|c||c|c|c|c|}
\hline Element & 718 & 706 & Waspaloy & 720 \\
\hline \hline $\mathrm{C}$ & .025 & .015 & .035 & .015 \\
\hline $\mathrm{Ni}$ & 53 & 41 & 58 & 57 \\
\hline $\mathrm{Fe}$ & 18 & 38 & - & - \\
\hline $\mathrm{Cr}$ & 18 & 16 & 20 & 16 \\
\hline $\mathrm{Mo}$ & 3 & - & 4.25 & 3 \\
\hline $\mathrm{W}$ & - & - & - & 1.25 \\
\hline $\mathrm{Co}$ & - & - & 13 & 15 \\
\hline $\mathrm{Nb}$ & 5.4 & 3.0 & - & - \\
\hline $\mathrm{Ti}$ & 1.0 & 1.75 & 3.0 & 5.0 \\
\hline $\mathrm{Al}$ & 0.5 & 0.25 & 1.3 & 2.5 \\
\hline $\mathrm{B}$ & .004 & .004 & .006 & .015 \\
\hline
\end{tabular}

\section{Alloy 718}

Alloy 718 is the most frequently used alloy for rotor quality aerospace applications. Due to the need for inclusion-free material and the tendency for segregation during melting and solidification, the primary production routes for rotor-quality material have evolved to vacuum induction melting (VIM) followed by either vacuum arc remelting (VAR), electroslag remelting (ESR), or both (ESR+VAR). Current production of double melted (VIM+VAR) ingot is limited to $508 \mathrm{~mm}$ (20 inch) diameter for high niobium levels. Larger double melted (VIM+VAR) ingots (610 mm - 24 inch) are produced, but their use is limited to non-rotor applications with reduced niobium. Typically, the niobium is at least $0.30 \%$ lower for these applications to prevent freckle formation. Freckles are regions of positive macrosegregation that result from the flow of solute-rich interdendritic liquid in the mushy zone during solidification. ESR ingots are limited to less than $432 \mathrm{~mm}$ ( 17 inch) diameter due to an increased tendency for freckle formation during ESR. Triple melted (VIM+ESR+VAR) 718 ingots offer the benefits of reduced inclusions from the ESR process along with a more solid electrode for VAR processing ${ }^{(1)}$. It has been a standard route to produce up to $508 \mathrm{~mm}$ (20 inch) diameter ingots for a number of years.

Larger and more aggressive engine designs such as the PW4084, Trent 800, and GE90 have led to a demand for larger diameter rotor-quality billet. Requirements are such that this diameter billet must have microstructure and sonic 
inspection capabilities comparable to smaller billet. To meet this demand. a program was undertaken to develop a $610 \mathrm{~mm}$ (24 inch) diameter ingot. Since the double melted (VIM+VAR) $610 \mathrm{~mm}$ diameter ingot is limited to lower niobium contents, it is not an option for these applications. High niobium is necessary to meet the mechanical property requirements Double melting is restricted by the lack of integrity of the VIM electrode. Cracks and solidification shrinkage cause instabilities during subsequent remelting. A more viable route seemed to be scaling up by triple melting where a solid ingot is generated in ESR that serves as the electrode in VAR. The enhanced process control obtained with the high integrity electrode results in a more stable VAR process. This reduces the tendency to form positive segregation such as freckles Various melt parameters were investigated by evaluating billet structures to optimize the process. Numerous $610 \mathrm{~mm}$ (24 inch) ingots have been melted with no occurrences of freckles in production material. The niobium content is the same high level used for smaller rotor quality ingots.

Macrostructural evaluation of billets produced by the triple melted $610 \mathrm{~mm}$ ( 24 inch) ingot route has revealed white spot frequencies typical of $508 \mathrm{~mm}$ ( 20 inch) triple melt product. White spots are light etching areas that are depleted in hardening elements ${ }^{12}$. Moderate tree ring patterns are sometimes observed as shown in Figure 1 for a top end slice. Figure 2 shows a typical macrostructure. These billet samples have been etched with Canada etchant to reveal melt related segregation.
More refined microstructures are possible for a given diameter billet when processed from a larger diameter ingot due to the greater amount of reduction. As a result, ultrasonic inspection capability is the same or better for a given diameter billet. Frequencies of occurrence for ultrasonic defects in triple melt material are low relative to double melted (VIM+VAR) products ${ }^{(3)}$. They are comparable for the 508 (20 inch) and $610 \mathrm{~mm}$ ( 24 inch) triple melted ingot routes (Figure 3 ). In this figure, the defect frequencies are for fine grain billet $254 \mathrm{~mm}$ ( 10 inches) in diameter and greater: they have been normalized to the frequencies for double melted billet from $508 \mathrm{~mm}$ ingots. Rejectable indications are typically cracks initiated from clusters of oxides, carbides and/or carbonitrides; often they are associated with white spots.

Carbide sizes can become larger and carbide distributions less desirable with increasing ingot diameter. Small $127 \mathrm{~mm}$ (5 inch) diameter ingots of alloy 718 made in Teledyne Allvac's pilot plant have smaller carbides than larger production ingots. For example, the $127 \mathrm{~mm}$ ingots have no carbides exceeding 20 microns, while a $160 \mathrm{~mm}^{2}\left(0.25\right.$ inch $\left.^{2}\right)$ metallography sample from the center of billet from a $508 \mathrm{~mm}$ (20 inch) diameter ingot can have over 25 carbide particles exceeding 20 microns. However, carbide ratings on billet from $610 \mathrm{~mm}$ ( 24 inch) diameter ingots and $508 \mathrm{~mm}$ ( 20 inch) diameter ingots have been found to be equivalent. Typical carbides are shown in Figures 4 and 5 for billet produced from ingots $508 \mathrm{~mm}$ (20 inches) and $610 \mathrm{~mm}$ ( 24 inches) in diameter. Reduction ratios of the billet shown are equivalent.
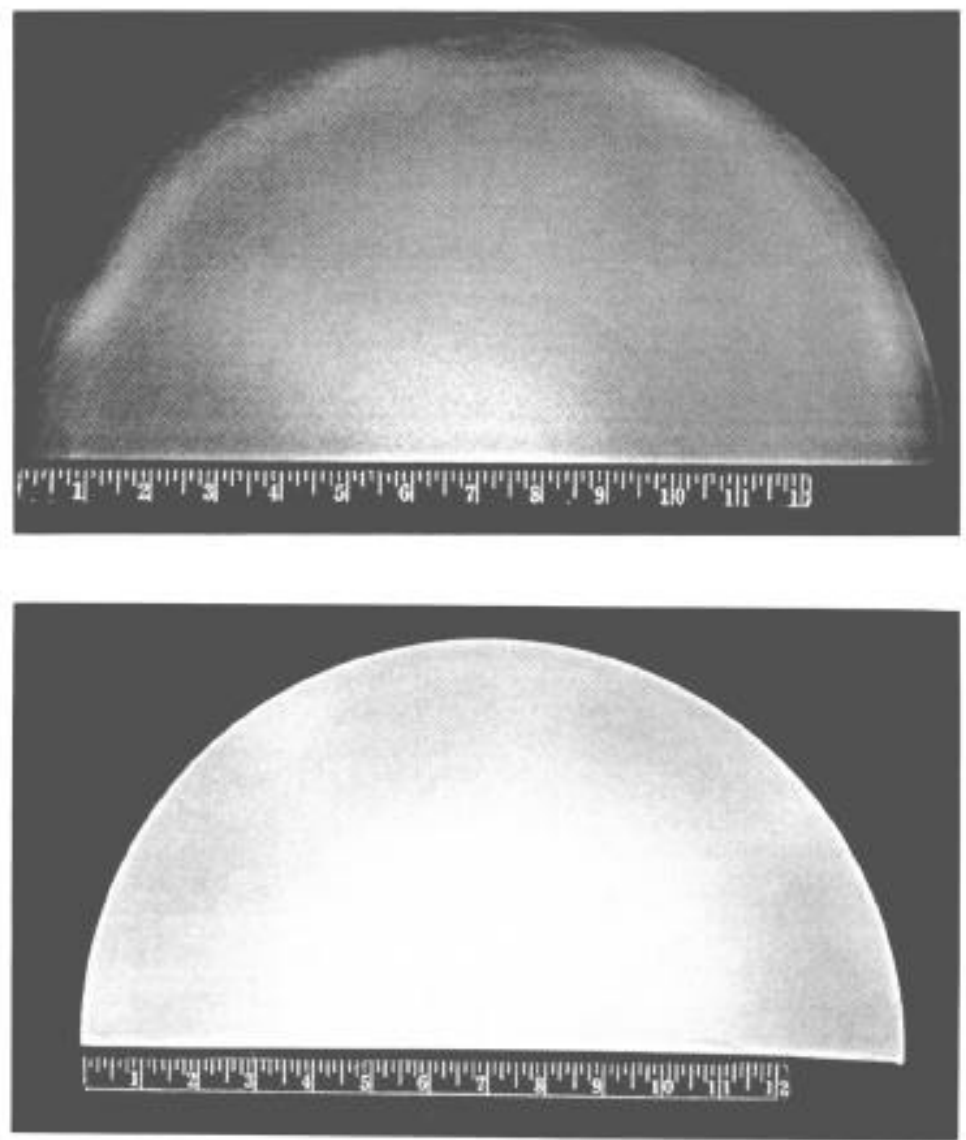

Figure 1: Moderate tree ring pattern in a billet slice from the top end of a $610 \mathrm{~mm}$ diameter ingot of triple melted alloy 718 . Canada etch. Scale is inches.

Figure 2: Typical macrostructure for a billet slice from a $610 \mathrm{~mm}$ diameter ingot of triple melted alloy 718. Canada etch. Scale is inches. 


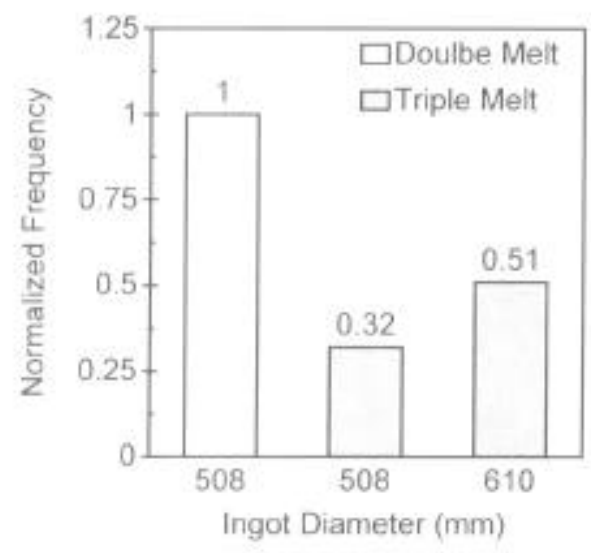

Figure 3: Relative frequencies of ultrasonic indications in alloy 718 billets $254 \mathrm{~mm}$ and larger from $610 \mathrm{~mm}$ triple melted ingots and $508 \mathrm{~mm}$ double and triple melted ingots. Data have been normalized to the frequencies for double melted $508 \mathrm{~mm}$ ingots.

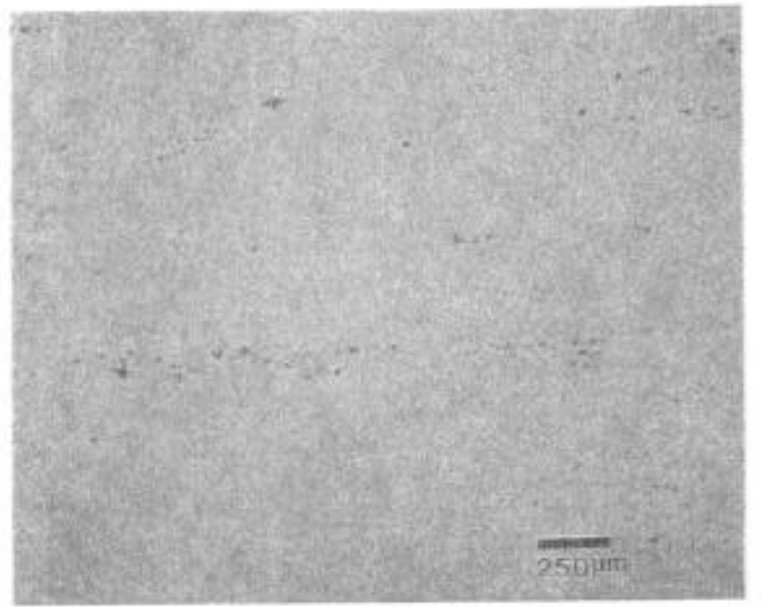

Figure 4: Typical carbide distribution for the bottom center location of $305 \mathrm{~mm}$ diameter fine grain billet from $508 \mathrm{~mm}$ diameter ingot.

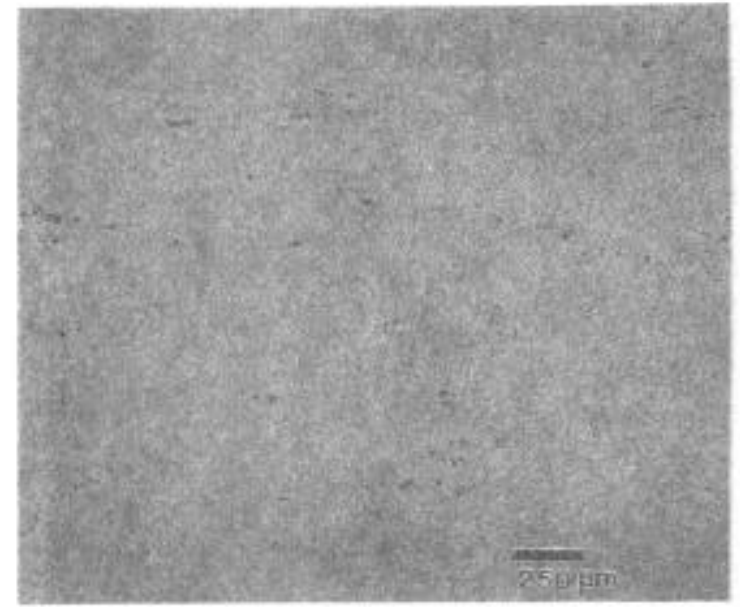

Figure 5: Typical carbide distribution for the bottom center location of $356 \mathrm{~mm}$ diameter fine grain billet from $610 \mathrm{~mm}$ diameter ingot.
Another concern with larger diameter alloy 718 ingots is increased microstructural segregation as manifested by banding with varying delta phase and niobium content. One method to evaluate this tendency is by determining delta solvus start temperatures by precipitating delta phase in a forged-down sample and establishing the temperature at which delta phase begins to dissolve. Evaluation of the $610 \mathrm{~mm}$ ( 24 inch) diameter ingot product has shown no increased tendency towards microsegregation relative to the $508 \mathrm{~mm}$ ( 20 inch) diameter triple melted product. Delta solvus start temperatures are equivalent.

Recently, the need has arisen for billet diameters and weights that can not be achieved from $610 \mathrm{~mm}$ ( 24 inch) diameter ingots. Therefore, a program directed towards extending triple melted ingots to $686 \mathrm{~mm}$ (27 inches) in diameter is underway. After several trials evaluating significant melt parameters, a process has been developed for successfully producing these large ingots. No freckles have been observed on any of the several production ingots made by this process.

\section{Alloy 706}

Following the development of alloy 718 , a patent was issued by the International Nickel Company in 1972 for alloy 706. One of the objectives of the alloy 706 development program was to establish an alloy that could be melted to larger cross sections than alloy 718 without segregation problems ${ }^{(1)}$. This was achieved primarily by reducing the niobium $(\mathrm{Nb})$ well below that for alloy 718 as shown in Table I. In the late 1980 's and into the 1990 's, this feature led to the use of large diameter alloy 706 ingots for heavy duty industrial gas turbine wheels. These forgings attain weights over 9,980 kgs. (22,000 lbs.) with diameters up to $2,210 \mathrm{~mm}$ ( 87 inches) and thicknesses exceeding $406 \mathrm{~mm}$ ( 16 inches) ${ }^{(5)}$. Teledyne Allvac provides ingots approaching $18,140 \mathrm{kgs}$. $(40,000 \mathrm{lbs}$. $)$ that are up to $914 \mathrm{~mm}$ (36 inches) in diameter for these forging applications. Diameters as large as $1,016 \mathrm{~mm}$ (40 inches) in diameter have been successfully melted.

Initial melting of these large diameter alloy 706 ingots involved double melting. Vacuum induction melting was followed by either VAR or ESR. However, it was found that segregation in the form of freckles sometimes occurred with double melting. In both 718 and 706 , freckles are enriched in $\mathrm{Nb}$ and usually contain Laves Phase and numerous carbides and/or carbonitrides. An extreme example of freckles in a double melted (MIM+ESR) 706 ingot $864 \mathrm{~mm}$ (34 inches) in diameter is shown in Figures 6 and $7^{(3)}$. Because of this problem, a triple melt process consisting of VIM+ESR+VAR was adopted.

It is necessary to control carefully the chemistry of large diameter 706 ingots to meet properties in final parts. Some of these chemistry controis, such as low silicon, carbon, and sulfur, also help to reduce the tendency of the electrodes to crack during heating and cooling and during melting. 
Macrostructures for large diameter alloy 706 ingots are free of positive segregation such as freckles. An example is presented in Figure 8, which shows a typical transverse cross section for a $914 \mathrm{~mm}$ ( 36 inch) ingot that has been double upset and drawn to a billet about $813 \mathrm{~mm}$ (32 inches) in diameter.

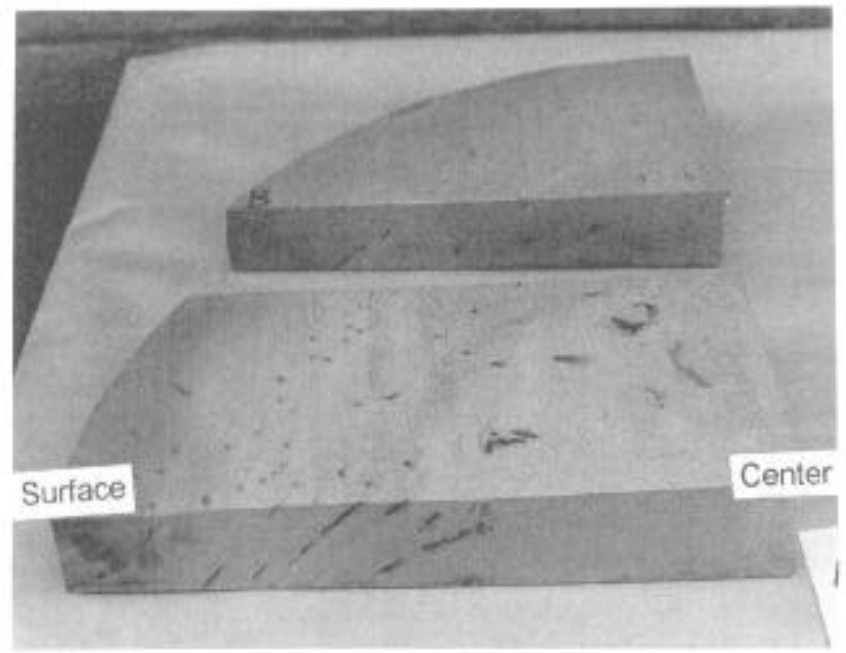

Figure 6 : Large freckles outlining the pool profile near the top end of an $864 \mathrm{~mm}$ diameter ingot of VIM+ESR alloy 706 . The topmost transverse face of the plate is on the ground.

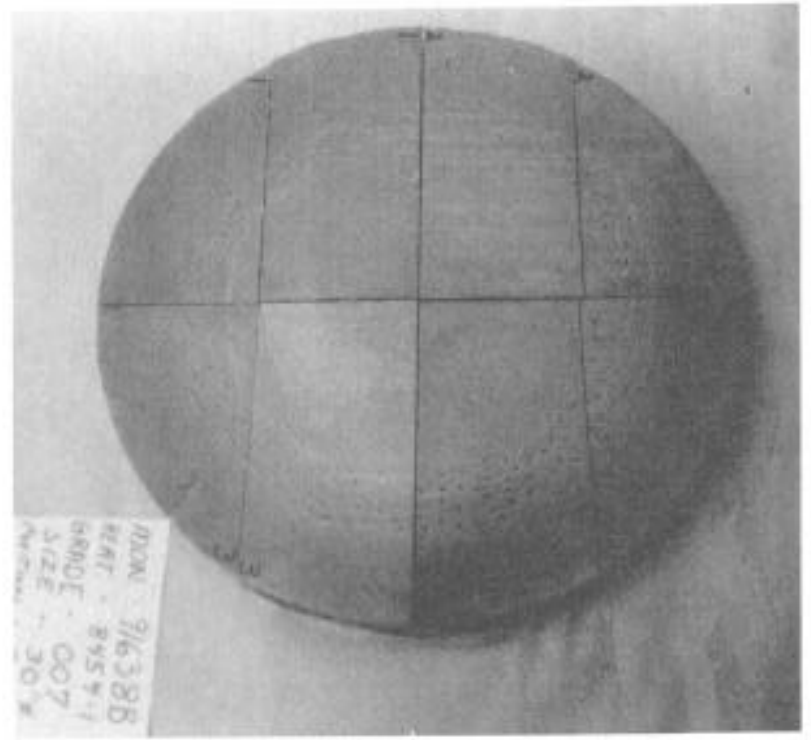

Figure 7: Pattern of freckles near the bottom end of the same $864 \mathrm{~mm}$ diameter ingot of alloy 706 pictured in Figure 6 .

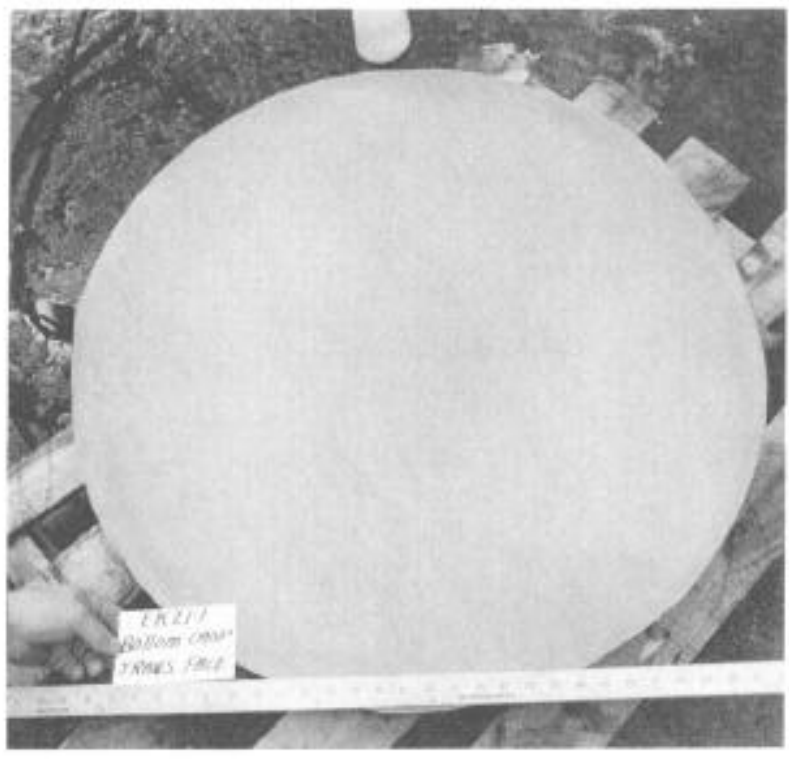

Figure 8: Typical macrostructure of a billet slice from a $914 \mathrm{~mm}$ diameter ingot of alloy 706 . Scale is inches.

\section{Waspaloy}

Another superalloy that has continued to be developed for cast plus wrought applications is Waspaloy. Millions of pounds have been produced each year by the VIM+VAR process as $508 \mathrm{~mm}$ ( 20 inch) and $610 \mathrm{~mm}$ ( 24 inch) diameter ingots and by the VIM+ESR process for ingots up to $508 \mathrm{~mm}$ ( 20 inches) in diameter. The design of larger aircraft engines has necessitated process development for production of even larger ingot sizes so that parts can be manufactured from larger diameter billets. In some cases, parts previously manufactured by investment casting can be replaced by wrought parts, which also has driven the development of larger ingots.

The ESR process was found to be limited to production of Waspaloy ingots no larger than $508 \mathrm{~mm}$ (20 inch) diameter due to macrosegregation. ESR parametric studies were performed in attempts to produce $610 \mathrm{~mm}$ ( 24 inch) diameter ingots. Although results were sometimes encouraging, it was concluded that the process window was too narrow and not viable as a production process. Ingots were sometimes found to contain freckle type macrosegregation without any indication from variations in critical ESR parameters. The ESR charts had normal traces for melt rate and voltage swing for both good and bad (freckled) sections of $610 \mathrm{~mm}$ ( 24 inch) ingot. State of art ESR processing could not meet the demand for larger ingot sizes.

Extending the VIM+VAR process to $762 \mathrm{~mm}$ (30 inch) diameter ingots for Waspaloy was readily accomplished. A $686 \mathrm{~mm}$ (27 inch) diameter, $10,900 \mathrm{~kg}$. (24,000 lb.) electrode was cast by the VIM process and then VAR processed under controlled conditions to explore the process window. This led to melting procedures that reproducibly provide satisfactory billet structures. Billet $457 \mathrm{~mm}$ (18 inch) in diameter is 
routinely produced from $762 \mathrm{~mm}$ ( 30 inch) VIM+VAR ingots with macrostructures comparable to billet produced from $610 \mathrm{~mm}$ (24 inch) VIM+VAR ingots.

\section{Alloy 720}

Alloy 720 is a gamma-prime strengthened nickel-base superalloy like Waspaloy but the titanium (Ti) plus aluminum (Al) content is significantly higher as shown in Table I. Therefore, alloy 720 is more prone to positive segregation, such as freckles, than Waspaloy. Also, the decreased ductility of alloy 720 increases the risks of thermal cracking and melt rate cycles. In the 1980's, the largest standard ingots were double melted (VIM+VAR) to $432 \mathrm{~mm}$ (17 inches) in diameter. As the requirement for larger disks and improved microstructures in the early 1990's intensified, the capability to produce triple melted (VIM+ESR+VAR) ingots $508 \mathrm{~mm}$ (20 inches) in diameter was developed. These are now routinely provided with no incidence of freckling or other positive segregation. Now there is a need for even larger ingots to provide billet for larger disks and for further grain structure refinement. Consequently, an effort is underway to determine the feasibility of producing a triple melted ingot $610 \mathrm{~mm}$ (24 inches) in diameter. It is recognized that a number of ingots must be successfully melted and fully evaluated to verify this process.

\section{Melt Processing}

\section{ESR vS VAR}

The VAR process results in a more controlled solidification of the ingot compared to the ESR process and is thus able to produce larger ingots of segregation sensitive alloys. ESR is complicated by the use of a $\mathrm{CaF}_{2}$ based slag to melt the electrode by resistance heating. The slag freezes on the water cooled copper crucible and forms a skin between the ingot and crucible. Thus, the slag cap insulates the top of the ingot and the slag skin insulates the $O D$ of the ingot. This results in a lower heat transfer rate during the ESR process and causes deeper molten pools and longer solidification times compared to VAR ${ }^{(6)}$. In VAR, the ingot is cast directly into the water cooled copper crucible and heat conduction is essentially unimpeded. Heat is radiated from the top of the molten pool between the electrode and crucible and transferred directly from the ingot to the crucible. Heat transfer between the ingot, which shrinks away from the crucible during solidification, is further enhanced by pressurizing the gap with helium. Heat is more efficiently conducted by the helium gas than if it were radiated from the ingot to the crucible. These factors contribute to shallower pools and reduced segregation in VAR relative to ESR.

\section{VAR Controls}

The VAR process is also preferred for larger diameter ingots of segregation prone alloys due to more reliable process controls. The process is controlled by regulating the electrode melting and ingot casting conditions. Electrode melting is automatically computer controlled using two algorithms. The first adjusts the electrode position in order to maintain a constant gap between the electrode and the molten metal pool, based on the arc voltage signal. F. J. Zanner ${ }^{(7)}$ established a model relating the electrode gap to the frequency of drop shorts, which are caused by molten metal being transferred from the electrode to the ingot pool. A molten metal droplet can temporarily bridge the electrode gap and appear as an instantaneous drop in voltage or drop short. As the gap increases, fewer of the molten droplets bridge the electrode gap and the drop short frequency decreases. The computer continually adjusts the electrode speed to maintain a constant drop short frequency and therefore, a constant arc gap. The second algorithm is used to adjust the arc current continually in order to maintain a constant electrode melt rate. The melt rate is calculated by the computer using electrode weights from the VAR furnace load cell weighing system.

The ingot casting conditions are controlled by establishing adequate crucible cooling conditions. These include water temperature, water flow rate, and helium pressure in the gap between the ingot and crucible. The combined effect of computer process control of the electrode melting and establishment of appropriate ingot casting conditions enables production of alloys in ingot sizes previously unobtainable.

\section{Melt Rate Cycles}

During ESR and VAR, anomalies associated with melt rate can occur. One of these is commonly referred to as a melt rate excursion or melt rate cycle. It is distinct from other anomalies by its unique signature as shown in Figure 9 , where the deviation in melt rate from the nominal melt rate is plotted versus time. A melt rate cycle starts with a gradual increase from the nominal steady state melt rate, followed by a rapid increase to a peak, a sudden decrease to a minimum, then gradual recovery to the nominal melt rate. When remelting ESR ingots as electrodes in VAR, the onset of the melt rate cycle is typically indicated by several pressure spikes up to 20-30 microns. Other melt rate anomalies usually are associated with a transient decrease in melt rate from steady state, such as that caused by a glow discharge or constricted arc in VAR.

Melt rate cycles in ESR and VAR are caused by imperfections in the electrode. The lack of appropriate thermal treatments of highly alloyed electrodes can result in internal transverse cracks. The crack interrupts the heat conduction along the length of the electrode from the end that is melting. This concentrates the heat below the crack, which causes the melt rate to increase as the process becomes more efficient. When the crack interface is reached, the end of the electrode is relatively cold, making the process less efficient. Therefore, the melt rate suddenly decreases. Finally, the melt rate gradually increases until the steady state temperature gradient is re-established in the electrode and the nominal melt rate is reached. A longitudinally sectioned and macroetched VIM electrode with a thermal crack is shown in Figure 10. The electrode is from a VAR melt that was aborted because of melt rate cycles. The melt rate cycle shown previously in Figure 9 is from the electrode in Figure 10. The longitudinal cracking in Figure 10 is pipe cavity from solidification shrinkage. The transverse crack 


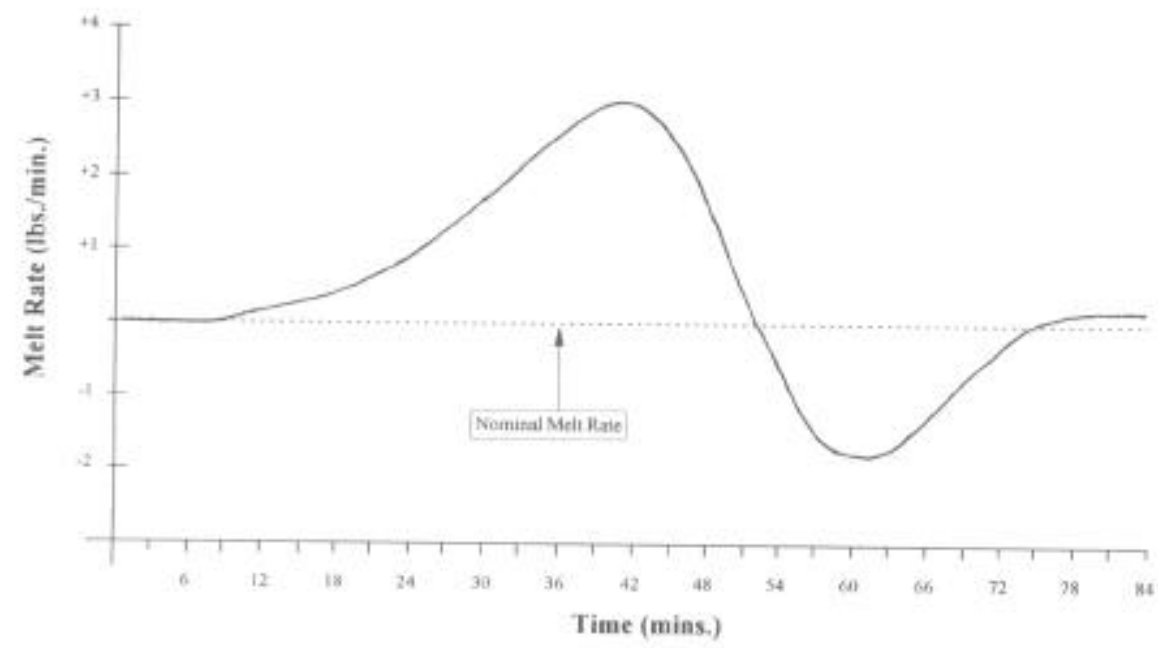

Figure 9: Melt rate cycle during VAR of the VIM electrode shown in Figure 10.

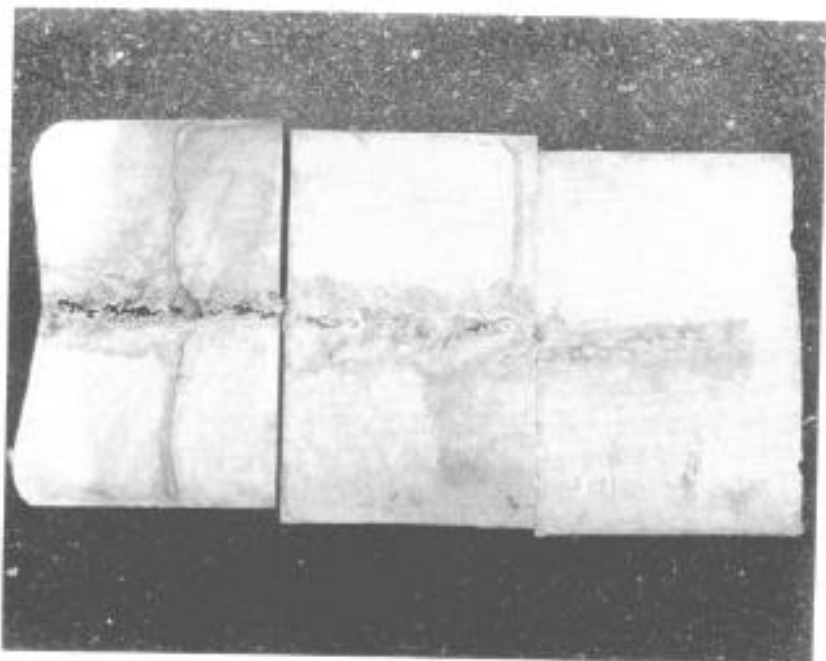

Figure 10: Longitudinal sections of VIM electrode aborted during VAR because of melt rate cycles, one of which is presented in Figure 9. Note transverse thermal crack in left section. Canada etch.

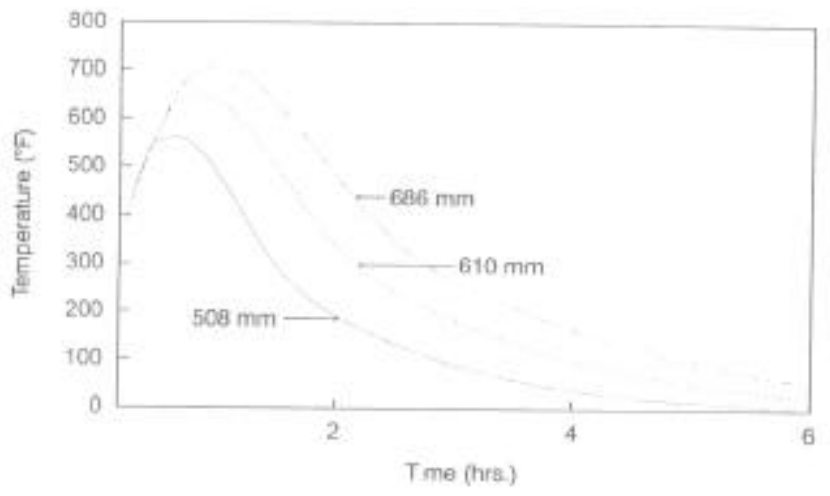

Figure 11: Calculated temperature difference from surface to center versus time when alloy 718 ingots at room temperature are put into a furnace at $1093^{\circ} \mathrm{C}$. near the left end of the electrode is the thermal crack. The left end of the electrode represents the surface being melted. The portion of the electrode shown was cut into three pieces to facilitate etching.

Evaluation of billets by macroetch and ultrasonic inspection has found acceptable structures for some melt rate cycles. Based on these evaluations, limits have been established for the severity of melt rate cycles for different alloy types and ingot sizes. In addition, the VAR and ESR control settings can be selected to react to the melt anomaly and reduce the variations in certain process parameters or ignore the melt rate cycle altogether, depending on the specific alloy and ingot size

\section{Thermal Treatments}

Melt rate cycles can be avoided or their effects minimized by appropriate thermal treatments of electrodes. Thermal treatments improve the ductility of the electrode so that it is less susceptible to cracking from internal stresses. These internal stresses are generated by thermal gradients during melting and from heating and/or cooling of the electrodes. In addition to improving ductility, appropriate thermal treatments decrease residual stresses from heating and cooling. As diameters become larger, residual stresses become more of a concern because of increased thermal gradients. This is illustrated in Figure 11, which shows the calculated temperature difference between the center and surface locations as a function of time when three different diameter alloy 718 ingots at room temperature are placed in a $1093^{\circ} \mathrm{C}$ $\left(2000^{\circ} \mathrm{F}\right)$ furnace. The larger temperature gradient for the $686 \mathrm{~mm}$ ( 27 inch) ingot will generate greater internal stresses and, therefore, have more tendency for cracking. Concern about thermal gradients extends beyond melting to heating and cooling for subsequent homogenization and conversion.

\section{Process Development}

Extensive process development is necessary to establish a robust process for producing larger diameter ingots for a specific alloy. Each step of the total melt process must be evaluated but special emphasis is placed on the final melt process where several melt parameters need to be 
evaluated. Both aim levels and limits (upper and lower) must be determined for these parameters. It is not sufficient to concentrate only on the steady state portions of the final meit process; start-up and hot topping procedures must also be examined. One of the final melt parameters for which the process window must be identified is melt rate. Positive segregation such as freckies occur when the upper melt rate limit is exceeded. When the melt rate extends below the bottom limit, excessive solidification white spots occur. An example is presented in Figure 12, which shows a transverse macro slice for a $305 \mathrm{~mm}$ ( 12 inch) billet forged from a $686 \mathrm{~mm}$ (27 inch) alloy 718 ingot with a low melt rate. The surface region contains numerous solidification white spots.

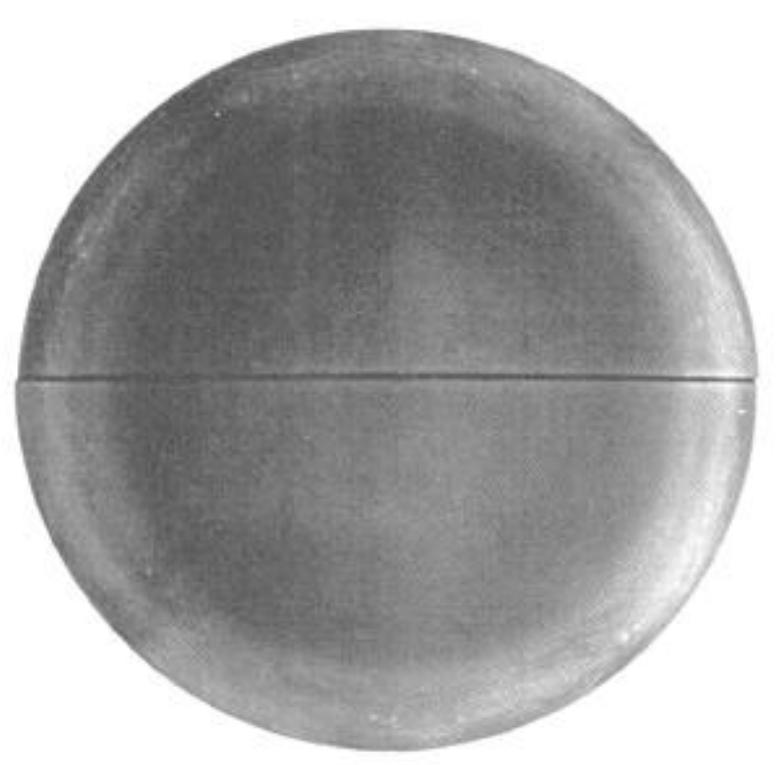

Figure 12 Solidification white spots in a $356 \mathrm{~mm}$ (14 inch) billet slice from a $686 \mathrm{~mm}$ ( 27 inch) ingot of 718 that was melted at a very low melt rate.

Modeling has been helpful for analyzing the feasibility of remelting large diameter ingots and for optimizing melt parameters. Performing simulations under different melt conditions can reduce the number of actual ingots that must be melted to establish a process. It is hoped as the ESR and VAR models are further developed and verified, they will become more useful in process development programs.

\section{Conclusions}

The demand of larger ingots for various superalloy systems is being met by continuous advances in melting controls, equipment, procedures, and understanding For some alloy systems, triple melting is necessary to meet macrosegregation requirements. Maximum ingot diameters that can be melted without segregation problems have been extended in the 1990 's to the sizes shown in Table II.
Table II. Present Ingot Diameter Capabilities that have Recently Been Extended

\begin{tabular}{|c||c|c|c|c|}
\hline \multicolumn{2}{|c||}{} & \multirow{2}{*}{$\begin{array}{c}\text { Melt } \\
\text { Plloy }\end{array}$} & \multicolumn{3}{c|}{ Maximum Diameter (mm) } \\
\cline { 3 - 5 } & Process & $\begin{array}{c}\text { Standard } \\
\text { Product }\end{array}$ & $\begin{array}{c}\text { Special } \\
\text { Product }\end{array}$ & $\begin{array}{c}\text { Under } \\
\text { Evaluation }\end{array}$ \\
\hline \hline 718 & VIM+ESR+VAR & 610 & 686 & \\
\hline 705 & VIM+ESR+VAR & 914 & & \\
\hline Waspaloy & VIM+VAR & 610 & 762 & \\
\hline 720 & VIM+ESR+VAR & 508 & & 610 \\
\hline
\end{tabular}

Acknowledgments: The authors gratefully acknowledge Ramesh Minisandram for providing the modeling results and Scott Vallandingham for providing information on alloy 720 .

\section{References}

1. A. Mitchell, "The Present Status of Melting Technology for Alloy 718", Superalloy 718 - Metallurgy and Applications, ed E. A. Loria, The Minerals, Metals \& Materials Society, 1989. $1-15$

2. L. A. Jackman, G. E. Maurer, and S. Widge, "New Knowledge About 'White Spots' in Superalloys;" Advanced Materials \& Processes, 5 (1993), 18-25.

3. J. M. Moyer et al., "Advances in Triple Melting Superalloys 718,706 , and $720^{\prime \prime}$, Superalloys 718,625, 706 and Various Derivatives, ed. E A. Loria, The Minerals, Metals \& Materials Society. 1994, 39-48.

4. H. L. Eiselstein, "Properties of Inconel Alloy 706", Materials Engineering Congress. Cleveland. 1970

5. P. W. Schilke, J. J. Pepe, R. C. Schwant, "Alloy 706 Metallurgy and Turbine Wheel Application", Superalloys 718. 625, 706, and Various Derivatives, ed. E. A. Loria, The Minerals, Metals \& Materials Society, 1994, 1-12.

6. K. O Yu, J. A Domingue, "Control of Solidification Structure in VAR and ESR Processed Alloy 718 Ingots", Superalloy 718 - Metallurgy and Applications, ed. E. A. Loria, The Minerals, Metals \& Materials Society, 1989, 33-48.

7. F. J. Zanner, "Vacuum Consumable Arc Remelting Electrode Gap Control Strategies Based on Drop Short Properties", Metallurgical Transactions B. American Society for Metals and the Metallurgical Society of AIME, Volume 12B. December 1981, 721-728. 